\title{
MINIMUM WAGE INSTITUTION IN THE FINANCIAL AND ECONOMIC CRISIS. POLICIES AND PRACTICES.
}

\author{
Valentina Vasile
}

\begin{abstract}
The economic and financial crisis became apparent in Romania somewhat delayed but persists and is aggravated due to the weak sustainability of the economic growth recorded in the last few years. The considerable diminishment of output because of reduced exports and domestic demand compression for goods and services generates new unemployed contingents and triggers the diminishment of employees' earnings. Additionally, the distribution of employees on income brackets places the median under the level of the average wage on economy and heightens incomes' inequality. In this context, the economic and social significance of the minimum wage increases from the perspective of sustaining domestic demand and from the social one of maintaining an adequate living standard, as well. In spite of the sizeable increase of the minimum wage during the transition period, it remains one of the lowest in EU and it does not exceed the minimum subsistence level. The paper presents the crisis impact on the labour market from the viewpoint of using the minimum wage as instrument of maintaining/stimulating domestic demand and social protection of employees and identifies the elements of adequate policies for the crisis situation and to the particularities of labour market and economic conditions in Romania.
\end{abstract}

Key words: minimum wage, finanacial crisis, labour market

JEL classification: J30, G01, J40

\section{Introduction}

The weak management of the economic crisis and the inefficiency of the "anticrisis" package of measures associated with a confuse elections' year, full of contradictions at political level, affected to a large extent the living standard of the Romanians, it increased the poverty risk and doubled the unemployment rate. If in the fourth quarter of 2008 discussions were about indirect and postponed effects of the crisis, and their marginal and low incidence on Romania's economy, in the $4^{\text {th }}$ quarter of 2009 we still face decreases of economic indicators for production and export, slightly attenuated against the period from the beginning of the year.

In this context, the economic and social significance of the minimum wage increases from the perspective of sustaining domestic demand and from the social one of maintaining an adequate living standard, as well. In spite of the sizeable increase of the minimum wage during the transition period, it remains one of the lowest in EU and it does not exceed the minimum subsistence level.

The economic crisis deepens, poverty incidence increases due to unemployment and low incomes

Actually, from a record economic growth for the EU are of 7.1\% in 2008, in 2009 Romania registers the highest economic constriction among the Member States, respectively of over 7\%. The Romanian economy was proved as very fragile and the effects more severe than anticipated. As an open economy, Romania was affected to a larger extent than expectations by the unfavourable

\footnotetext{
${ }^{1}$ Professor PhD, Scientific director of Institute of National Economy, Romanian Academy
} 
external environment ${ }^{2}$. At the same time, the contraction of the domestic demand proved to be a lot more severe.

The most significant disadvatages that Romania faced in the crisis period could be consider the following:

a) a week sustainability of the last years of economic growth favourised one of the most severe economic decreaseamong EU countries. The contraction of the economic activity as of the fourth quarter 2008 and the marked economic diminishment was in the first quarter 2009 as compared with the first quarter $2008-6.2 \%(-4.8 \%$ at EU-27 level) on the background of a diminished value of GDP/inhabitant, and the economic decrease continued, GDP for the second quarter being lower, in real terms by $8.7 \%$ against the first quarter 2009 (-4.9\% at EU-27 level). In the third quarter of 2009, the diminishment continues, the GDP in real terms being by $0.7 \%$ lower as compared with the second quarter (adjusted data) and by $7.1 \%$ against the comparable period of from 2008 (-4.3\% at EU 27 level). For the first 9 months of the year 2009 was recorded a GDP contraction of $7.4 \%$ against the similar period of the year 2008 ;

Table no. 1

Growth rate of GDP in volume (based on seasonally adjusted data)

\begin{tabular}{|l|c|c|c|c|c|c|c|c|c|c|}
\hline & \multicolumn{4}{|c|}{ Percentage change compared with } \\
\cline { 2 - 11 } & \multicolumn{4}{|c|}{ As previous Q } & \multicolumn{3}{c|}{ The same Q of the previous year } \\
\cline { 2 - 11 } & 2008 & \multicolumn{3}{|c|}{$\mathbf{2 0 0 9}$} & \multicolumn{2}{c|}{ 2008 } & \multicolumn{3}{c|}{$\mathbf{2 0 0 9}$} \\
\hline & Q3 & Q4 & Q1 & Q2 & Q3 & Q3 & Q4 & Q1 & Q2 & Q3 \\
\hline EU 27 & -0.4 & -1.9 & -2.4 & -0.3 & 0.3 & 0.6 & -1.8 & -4.9 & -5.0 & -4.3 \\
\hline $\begin{array}{l}\text { Romania } \\
(*)\end{array}$ & -0.1 & -2.8 & -4.6 & -1.1 & -0.7 & 9.2 & 2.9 & -6.2 & -8.7 & -7.1 \\
\hline
\end{tabular}

(*) percentage change compared with the same Q of the previous year; nonseasonally adjusted. Source: Eurostat newsrelease 144/2009 - 7 october 2009, 173/2009 - 3 December 2009 The most affected sectors, which generated also significant personell and incomes cutoffs, were constructions, trade and some of the industrial activities, as well as several consumption services.

Table no. 2

Gross Domestic Product evolution in Romania during current crisis

\begin{tabular}{|l|r|r|r|}
\hline & Q1 2009 & Q2 2009 & \multicolumn{1}{c|}{ Q3 2009 } \\
\hline $\begin{array}{l}\text { GDP current } \\
\text { prices - } \\
\text { million lei }\end{array}$ & 128727,9 & 109930,1 & $-0.6 \%$ \\
\hline $\begin{array}{l}\text { Indices } \\
\text { against } \\
\text { previous Q \% }\end{array}$ & -4.6 & -8.7 & 127780,0 \\
\hline $\begin{array}{l}\text { Diminishment } \\
\text { of the activity }\end{array}$ & $\begin{array}{l}\text {-agriculture, forestry } \\
\text { and fishing (-7.6\%), }\end{array}$ & $\begin{array}{l}\text {-agriculture, forestry and } \\
\text { fishing (-9.1\%), }\end{array}$ & $\begin{array}{l}\text {-constructions (-5.5\%), } \\
\text { - trade, car and }\end{array}$ \\
\hline
\end{tabular}

\footnotetext{
${ }^{2}$ Economic volatility became rapidly marked in the first months of 2009. In the month of February the World Bank representatives indicated an economic growth of $0-2 \%$ in Romania for the current year, revised in minus from the estimate of 3.2\% included in the report Global Economic Perspectives 2009 presented in the month of December of last year. Thereafter, a contraction of $4 \%$ was estimated, and in September the estimates were of 7.5-6\%. The World Bank singled amongst the most important risks the crash of foreign capital flows towards emergent economies, the strong deterioration of the commercial activity and the abrupt decrease of demand for export, as well as at domestic level.
} 


\begin{tabular}{|c|c|c|c|}
\hline volume & $\begin{array}{l}\text {-industry }(-1.4 \%), \\
\text { - trade, car and } \\
\text { household items repair, } \\
\text { hotels and restaurants, } \\
\text { transports and } \\
\text { communications (- } \\
3.7 \%) \\
\text {-constructions }(-0.3 \%) \\
\text {-net taxes on product (- } \\
2.1 \%) \text {. }\end{array}$ & $\begin{array}{l}\text { - industry }(-7.3 \%), \\
\text {-constructions }(-14.2 \%), \\
\text { - trade, car and } \\
\text { household items repair, } \\
\text { hotels and restaurants, } \\
\text { transports and } \\
\text { communications } \\
(-11.4 \%) \\
\text { - financial activities, real } \\
\text { estates, rentals and } \\
\text { services to enterprises (- } \\
7.4 \%) \text {. } \\
\text { - the volume of net taxes } \\
\text { on product collected to } \\
\text { the state budget recorded } \\
\text { a decrease by - } 13.6 \% \text {. }\end{array}$ & $\begin{array}{l}\text { household items repair, } \\
\text { hotels and restaurants, } \\
\text { transports and } \\
\text { communications } \\
(-2.6 \%) \\
\text { - other services }(-1.4 \%) \text {. } \\
\text { - the volume of net taxes } \\
\text { on product collected to } \\
\text { the state budget recorded } \\
\text { a decrease by }-4.4 \% \text {. }\end{array}$ \\
\hline $\begin{array}{l}\text { Use of Gross } \\
\text { Domestic } \\
\text { Product }\end{array}$ & $\begin{array}{l}\text { Total final } \\
\text { consumption } \\
\text { diminished by } 1.6 \% \\
\text { mainly due to } \\
\text { diminishing the } \\
\text { spending on individual } \\
\text { final consumption of } \\
\text { public administrations } \\
(-7.3 \%) \text { and of the } \\
\text { collective effective } \\
\text { final consumption of } \\
\text { public administrations } \\
(-14.7 \%) \text {. } \\
\text { The spending on final } \\
\text { consumption of } \\
\text { population households } \\
\text { diminished by only } \\
0.5 \% \text {. }\end{array}$ & $\begin{array}{l}\text { Total final consumption } \\
\text { diminished by } 12.0 \% \\
\text { The spending for the } \\
\text { final consumption of } \\
\text { population households } \\
\text { diminished by } 15.0 \\
\text { percents, as consequence } \\
\text { of the goods sales by } \\
\text { retail trade }(-20.6 \%) \text { and } \\
\text { of services supplied to } \\
\text { population }(-20.4 \%) \text {. }\end{array}$ & $\begin{array}{l}\text { Total final consumption } \\
\text { diminished by } 1.1 \% \\
\text { The spending for the } \\
\text { final consumption of } \\
\text { population households } \\
\text { diminished by } 1.4 \\
\text { percents and of the } \\
\text { collective effective final } \\
\text { consumption of public } \\
\text { administrations }(-1.5 \%) \text {. }\end{array}$ \\
\hline $\begin{array}{l}\text { Gross } \\
\text { formation of } \\
\text { fixed capital - } \\
\text { as against } \\
\text { previous Q -\% }\end{array}$ & -7.1 & +4.9 & -4.6 \\
\hline Export & $\begin{array}{l}\text { Exports of goods and } \\
\text { services }(-8.1 \%)\end{array}$ & +5.0 & +4.9 \\
\hline Import & $\begin{array}{l}\text { Imports volume of } \\
\text { goods and services (- } \\
4.3 \%) \text {. }\end{array}$ & +3.1 & +3.9 \\
\hline
\end{tabular}

GDP - seasonal adjusted data ${ }^{3}-$

${ }^{3}$ Next to the gross estimates of the quarterly Gross Domestic Product, as of 2009, are computed also the seasonal adjusted estimates by the regressive method, method recommended by the European regulations. The data regarding 
Source: NIS, Press release no. $168 / 2009$.

To these are added yet two other aspects, that is the constriction of export output and the marked contagion phenomenon in the Central and East European area from country to country, respectively considerable economic decreases, disinvestments of the companies, heightened unemployment, brutally adjusted deficits of the current account, fiscal deficits increasing significantly (NBR (2009), Report on financial stability June 2009, p 10);

b) Investments in the first 9 months of the year 2009 against 2008 were lower by about $22 \%$, especially because of investments' diminishment for equipment and machinery by about $40 \%$. By broad industrial groups, decreases were registered in durable goods industry $(-15.7 \%)$, in intermediate goods industry $(-12.9 \%)$, in current goods industry $(-9.2 \%)$, in capital goods industry ($6.3 \%)$ and in energy industry (-1.0\%). Industrial output remains lower than in 2008 by 8.5 percents, with the most severe reductions of activities recorded in mining and quarrying $(-11.8 \%)$ and manufacturing (-9.7\%). Diminishments of over $20 \%$ were recorded in: manufacture of basic metals $(-44.4 \%)$, manufacture of other non-metallic mineral products $(-28.6 \%)$, manufacture of textiles ($26.5 \%)$, manufacture of wearing apparel $(-25.8 \%)$, manufacture of leather and related products ($23.8 \%$ ), manufacture of chemicals and chemical products $(-21.5 \%)$, manufacture of computers, electronic and optical products $(-21.3 \%)$; the value of construction works registered a fall by $14.0 \%$.

c) the slow-down of the actual convergence process due to moderate productivity growth which was under the EU-27 average (the diminishment of the personnel is lower than the production contraction);

d) diminishment of the credit market due to the increased difficulty to access financing (reluctance of investors, the country rating decreases under the investment grade) and the dependency on the foreign banking capital - the share in total assets of the banks with foreign capital in 2008 was of 88.3 and in the first quarter 2009, 86.7. From total foreign capital the shareholders on countries at the end of the month March 2000 were as follows: $30.7 \%$ Greece, $23.5 \%$ Austria and $11.9 \%$ the Netherlands.

e) the most considerable increase of inflation as compared with EU Member States - the target for this year is of 3.5\% and the value recorded in October 2009/October 2008 is of $4.3 \%{ }^{4}$.

These developments cannot ensure short-term economic turnaround, so that the extension of the crisis period is to be expected in an optimistic approach up to the second half of the next year with serious effects on employment and population incomes.

The Government anti-crisis measures were much delayed and their nature was rather to moderate the effects and not to eliminate the reasons/ causes/factors and support the re-launch by using adequate levers.

\section{Implication of the crisis on labour market. Role of the minimum wage}

The economic-financial crisis has a significant impact on labour market, on one hand due to the reduction of economic activities, decrease of exports and diminished investments and, on the other hand because of enforcing anti-crisis measures meant to reduce the budgetary deficit by cutting budgetary expenditures. The measures taken on the labour market considered:

quarterly GDP - gross and seasonal adjusted series- for the period Q1 2000 - Q1 2009 shall be published on the NIS site: www.insse.ro.

${ }^{4}$ Romania registered the highest annual rate of inflation in the EU area in the period April-September 2009 (Eurostat data, according to Agerpres. Annual inflation rate decrease in a small proportion in September, at $4.94 \%$, but the prices for goods increased by $0.39 \%$ as against August 2009, as a result of increased prices at non food goods and services. In August, annual rate of inflation registered $4.96 \%$ (NIS data). 
- diminishing earnings of the private sector based on the constriction of economic activities and diminishing/eliminating some supplements or bonuses provided to the employees;

- layoffs by temporary reduction of activity, technical unemployment or activity termination;

- cutting off personnel expenditures corresponding to state employees by eliminating supplements, indemnities diminishment, giving up the payment of overtime (and compensation with free time), decreasing working time or unpaid furlough, layoffs by reorganising central and local structures of the State administration and reorganisation of governmental agencies;

- suspending the payment of some complementary earnings to the wage such as providing lunch tickets, gift and holiday vouchers, the payment of transportation costs, etc.;

The main effects felt on the labour market aimed at:

a) Increased unemployment and employment precariousness The biggest challenge for the labour nowadays is jobs. A visible and striking consequence of the crisis on the labour markets is the increasing number of unemployed people in 2008 and 2009 which will continue in 2010. After several years of consecutive decline, the ILO unemployment rate in Romania increased to $6.9 \%$ in Q 1 2009, higher for men 7.9\% and in the urban area 7.5\%. The number of unemployed increased in October for the $16^{\text {th }}$ month in a row, reaching the maximum level of the last five years and four months, respectively 654 thousand persons at the end of October 2009, and the unemployment rate increased to $7.1 \%$, from $6.3 \%$ in July. The unemployment rate estimated by the end of 2009 is of $7.5 \%$ and for the first part of 2010 it will continue to increase up to about $8.5 \%$, being, up to now, the most dynamic increase of the unemployment rate among the EU Member Countries, and more than double against the comparable period of 2010.

Unemployment magnitude is different on counties, the highest rate of unemployment being recorded in county Harghita (9.3\%) and the lowest in county Ilfov and Bucharest Municipality $2.1 \%$.

The increase of the number of unemployed among young shall be more marked, particularly due to the new graduates and to the return of some of the migrant workers. The most affected are young of up to 24 years of age, the unemployment rate being up to over 3 times higher, respectively $19.2 \%$. The majority of new entrants end up in the informal sector which is likely to become a refuge for young people. The job supply does not cover even $2 \%$ from the number of unemployed, and is reduced by half in sectors such as real estate and banks/finances-accounting, constructions and car industry. Romania has recorded significant job losses in commodity production export-oriented sectors, tourism etc. Some of the job losers are moving back to the rural areas or taking up informal job in the urban zones. Most requests for employment come from students and graduates, and from those with less than 3 years of experience. Additionally, employment precariousness increased markedly some jobs remaining part-time, or being temporary blocked. The limited capacity of the economy to react is reflected by the decreasing level of vacancy job rate (1.27 in Q1 2009 and 0.89 in Q2) and by the profile of labour demand. It should be mentioned that the effect of the crisis is different at territorial level, job vacancy highest rate being registered in North-East and Bucharest-Ilfov regions (by up to 50\% higher).

Another issue that becomes chronic for the labour market is represented by the difficulty to reverse the tendencies of high raises in long-term unemployment and large labour market "informality" is marked by migration from urban to rural areas and return labour force from abroad.

b)Diminishment of the purchasing power of wages, increased risk of poverty. The impact of the crisis on labour market goes beyond job losses by increasing informal employment and working poverty, intensifying pre-existing short comings.

For the first time in the last decade, in 2009, the real wage of the Romanians shall be lower than in the preceding year, the decrease being of $1.9 \%$, in accordance with the data of the National Commission for Prognosis (CNP), which anticipates a return to plus only for 2011. The last annual decrease of the real wage occurred in 1999 , when this indicator represented $97.5 \%$ from the value 
recorded a year before. The decrease took place then due to the loss of purchasing power of the national coin, the inflation rate being in the respective year of $54.8 \%$. Afterwards the indices increased on a yearly basis, and the increase of 2008 was of $13.9 \%$. According to the experts, the diminishment of the real wage is generated from the private sector. In the processing industry, for instance, the net average earnings of February 2009 was by $11 \%$ lower than the one of December 2008, and the inflation in February 2009/December2008 was of $2.13 \%$ ". Still, CNP estimates that the net average wage shall increase in 2009 and in 2010 to 1.328 lei and, respectively, 1.375 lei, as compared with the level of 1.280 recorded by the end of last year. As compared with 2009, earnings in real terms shall be maintained at the same level in 2010 and shall record an increase of $1.1 \%$ in 2011, in accordance with the CNP data.

c) Return migration. The current period of economic crisis brought also, naturally, a certain type of "contraction" of the Romanian migration 5 by diminishing the number of labour migration abroad and increasing the number of returns ${ }^{6}$. Of course, the evolutions related to the effective return into the country are depending on the particular forms that the economic crisis shall take in Romania, in the immigration countries, but also on the immigration policies of the respective countries.

We appreciate that the effects on labour market shall be multiplied and the impact will increase, both under the aspect of unemployment growth, but also at the level of earnings, especially with respect to the purchasing power of labour incomes, employability, job creation rate, etc. All these negative factors are causing a long-lasting crisis with significant social hardship, deepening the employment crisis.

\section{Minimum wages as instrument of sustaining domestic demand and support for diminishing poverty risk}

Romania, as an open economy has among the very few solutions for economic downturn the increase of the domestic demand for goods and services. This implies also preserving the purchasing power of wage incomes. But Romania is faced with low level incomes, among the lowest in EU and with a distorted distribution of employees on wage brackets, with a high concentration below the average level of wage incomes. The distribution of employees after the gross wages achieved in the month of October 2008 indicates that $4.9 \%$ out of the employees' number who have worked at least 23 days full-time equivalent have achieved under and at the level of the minimum wage on economy (540 lei). The distribution of employees after achieved gross

\footnotetext{
${ }^{5}$ After the returns into the country at the end of the year 2008 and at the beginning of 2009 , it is likely that abroad are still approximately 2.5 million persons who emigrated for an undetermined period. Approximately $40 \%$ from them are in Italy and about $30 \%$ in Spain. In the last period the labour migration abroad are in their vast majority of the family type. Immigrants residing legally and temporary in Romania at the end of 2008 numbered about 60 thousands. The main EU countries from which immigrants arrive are Italy, Germany and France and from the immediate neighbourhood of the country Hungary, Bulgaria and Greece. In the last 5 years, the number of work permits issued to foreigners increased over 10 times from only 1364 work permits in 2004, to 14349 in 2008. It is a marked increase, if compared with the one in neighbouring countries with higher immigration experience, such as Poland.

${ }^{6}$ The share of Romanians who in the autumn of 2008 had structured intentions of returning in the country from abroad could be estimated, in accordance with partial survey data to less than 3-\% from total persons abroad. The persons who know less the language of the host country interact less with local population are more unsatisfied with the effects of migration on their own family and on their own health and have a positive perception on the economic future of their own country, tending to adopt to a higher extent the decision of returning into the country. In Italy and Spain, despite contractions associated with the crisis, the Romanian immigrant communities shall continue to increase by employment, housing, social networks and social integration at the level of the first and second generation of immigrants. Even if the return rate shall increase, it would be wrong to expect an inflow of migrant Romanians returning to the country. Social risks and inequities in Romania, Synthesis of the Report, Presidential Commission for the Analysis of Social and Demographic Risks, Presidential Administration, September 2009.
} 
wages reveals a gathering in the area of wages under 1500 lei, both for women $(62,8 \%)$, and for men $(59,6 \%)$.

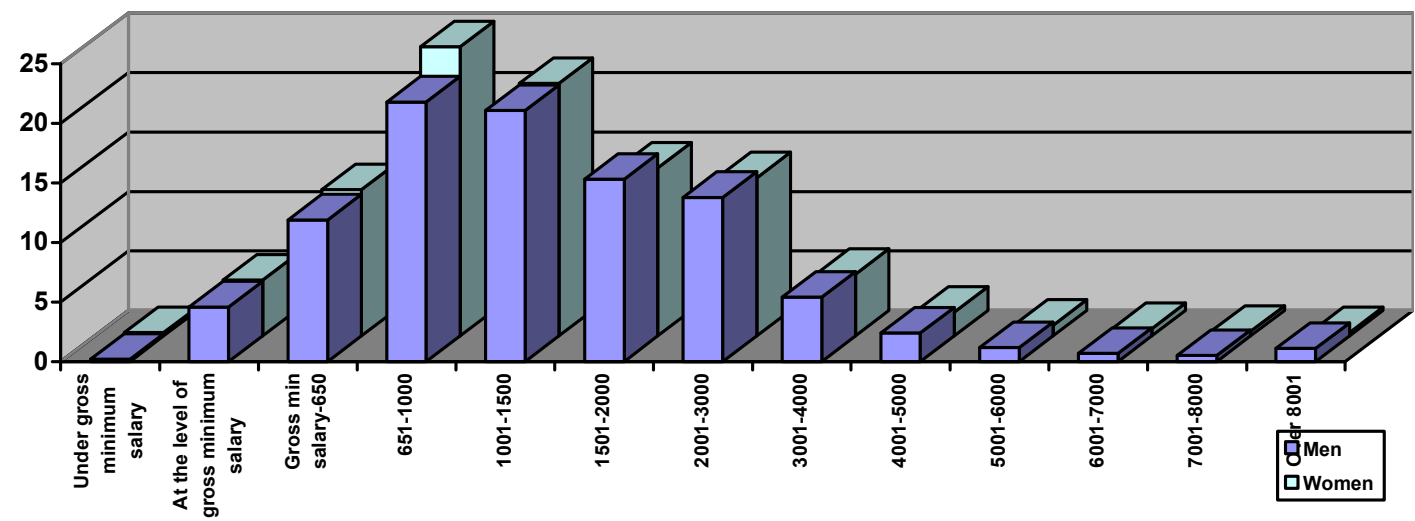

Fig. no. 1 - Distribution of employees on genders and wage categories (after achieved wages) in the month of October 2008

Source: National Institute of Statistics, Press Release no.78/2009

As result, the ratio between the minimum and average wage is of about $1 / 3$ under the conditions in which in other EU member countries this ratio is closer to the target of $50 \%$.

In a comparative perspective, the relationship between minimum and average wage in Romania is lower than in many EU countries. It decreases from $60 \%$ in March 1991 to fewer than $20 \%$ in 1996 - 1997, with monthly variations - the lowest value of the ratio was recorded in the month of December 1996 (the month in which as a rule the employees received Christmas bonuses and yearly premiums. In January 2000 the ratio is yet again under $20 \%$, but by increasing the minimum wage from 45 to 70 lei/month the ratio increases to $31 \%$. After 2000 the ratio varies around $30 \%$, all measures of increasing the minimum wage failing to improve these ratio, because of the policy of "shifting upwards the entire wage grid" due to the indexing of the minimum wage, without a law stipulation about this.

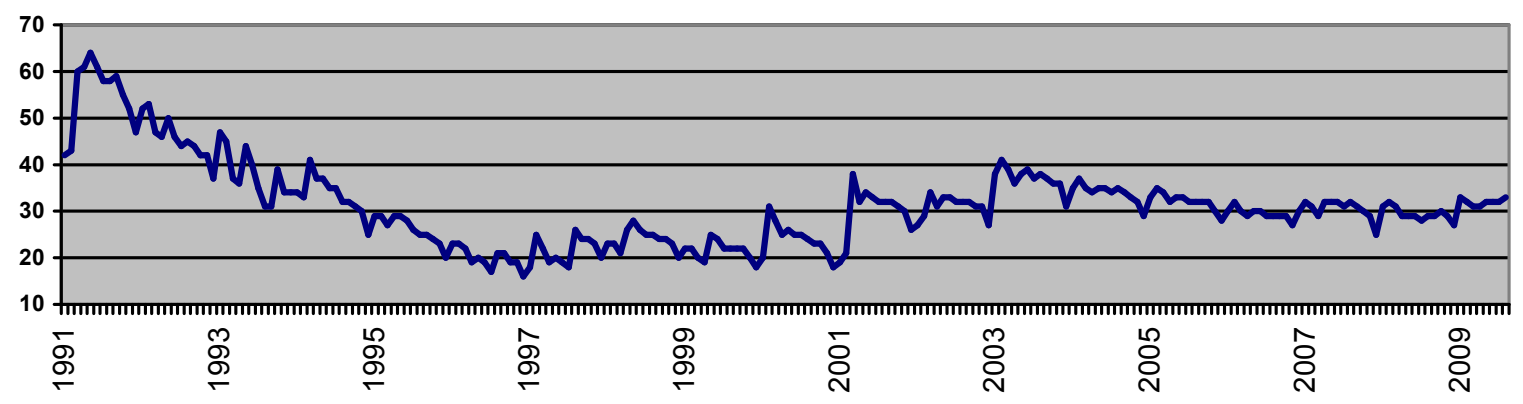

Fig. no. 2 - Minimum gross wage as share of average gross monthly earning, 1991-2009 (\%) Source: NIS data

The level of the minimum wage in Romania cannot generate significant increases of domestic demand, hence cannot considerably support the required economic growth for relaunching activity and recuperating the gaps, remaining dependent on exports and foreign direct 
investments. In real terms, against October 1990, the minimum wage represented in January 1999 around $24 \%$, and in January 2009, $77 \%$, hence the nominal increase from the period February 2000 - January 2009 of 8.57 times meant in real terms a purchasing power 2.59 times higher but without reaching the purchasing power of October $1990^{7}$.

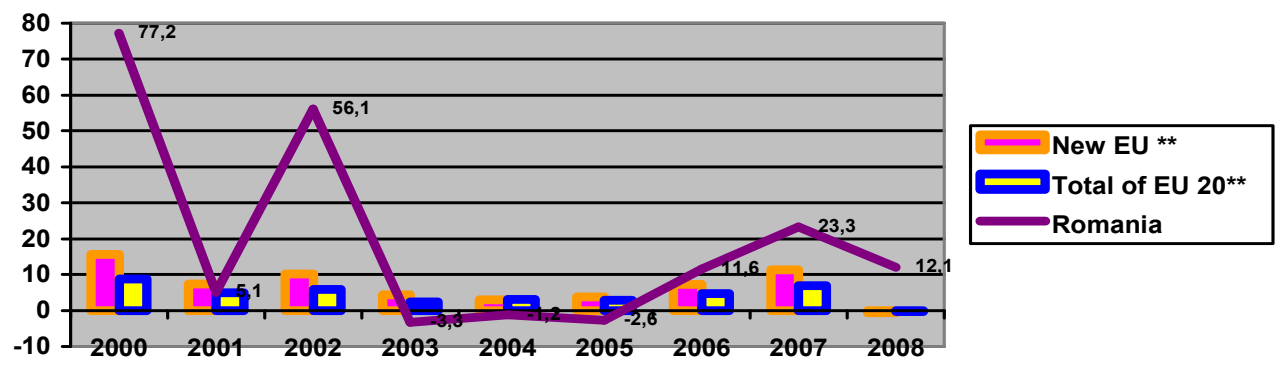

Fig. no. 3 - Real increase of the statutory minimum wage per hour (2000-2008) as percentage over the previous year (*)

* The amounts of minimum wages are compared on 1 January of each year. The real minimum wages calculations are based on the harmonised consumer price ** Unweighted average Source: WSI Minimum Wage Database 2009

From the viewpoint of the statutory minimum wage per hour, Romania is included among the groups of EU states with minimum wages of below 2 euro. Statutory minimum wages per hour, in January 2009 in euro ${ }^{8}$ was 0.96 , just below Bulgaria (0.71) and in PPS ${ }^{9} 1.62$.

The minimum wage level increased in Romania from 35 euro in January 2000 to 142 Euros in January 2009.

Table no. 3

Minimum wage level (January every year)

\begin{tabular}{|l|l|l|l|l|l|l|l|l|}
\hline & 2002 & 2003 & 2004 & 2005 & 2006 & 2007 & $\begin{array}{l}2008 \\
\text { (July) }\end{array}$ & 2009 \\
\hline Minimum wage level (euro/month) \\
\hline $\begin{array}{l}\text { Romania } \\
(2000=35)\end{array}$
\end{tabular}

\footnotetext{
${ }^{7}$ The minimum wage was implemented in Romania in the year 1991 (GR 133 from February) and the policy of settling its level reflected the economic and social objectives pursued in each stage - affordability for employer and social protection for employees. The development of the minimum wage in Romania reflected the dynamics and expectations of the transition period, without always fulfilling the function for which it was created/changed/updated as level and enforcement/compliance with procedure. The repeated changes of the aforementioned are evidence of the fragility and low efficiency of economy. In the period 1991-1999 the minimum wage was changed 25 times and up to 2000 yet another 12 times. From 0,2 RON net per month approx. 0,2350 RON gross) in October 1990 it reached in April 1998 to 35 RON gross, in February 2000 to 70 RON and in January 2009 to 600 RON

${ }^{8}$ on 1 January 2009; Calculation in EUR on the basis of the average exchange rate in 2008, Source: WSI Minimum Wage Database 2009

${ }^{9}$ on 1 January 2009; PPS calculated by EUROSTAT for the year 2006 Source: WSI Minimum Wage Database 2009
} 


\begin{tabular}{|l|l|l|l|l|l|l|l|l|}
\hline $\begin{array}{l}\text { Minimum } \\
\text { level EU - } \\
\text { Bulgaria }\end{array}$ & 51 & 51 & 61 & $\begin{array}{l}\text { Romania } \\
(77 \\
\text { Bulgaria })\end{array}$ & 82 & 92 & 112 & \\
\hline USA & 1001 & 877 & 727 & 666 & 753 & 676 & 652 & \\
\hline Minimum wage level at PPS/month \\
\hline Romania & 136 & 195 & 160 & 160 & 189 & 204 & 232 & $\ldots$ \\
\hline $\begin{array}{l}\text { Maximum } \\
\text { level EU } \\
\text { Luxembourg }\end{array}$ & 1369 & 1207 & 1322 & 1383 & 1417 & 1503 & 1532 & \\
\hline $\begin{array}{l}\text { Minimum } \\
\text { level EU- } \\
\text { Bulgaria }\end{array}$ & 127 & 155 & 143 & 179 & 191 & $\begin{array}{l}\text { Romania } \\
(216 \\
\text { Bulgaria) }\end{array}$ & $\begin{array}{l}\text { Romania } \\
(245 \\
\text { Bulgaria) }\end{array}$ & \\
\hline USA & 826 & 798 & 797 & 779 & 779 & 779 & 882 & \\
\hline
\end{tabular}

Source: Eurostat, Statistics in focus - Population and social conditions - 10/2009

The minimum wage in Romania was in 2008 by 11.75 lower than in Luxemburg and by $22 \%$ higher than in Bulgaria. Against the year 2002, the difference with Luxemburg diminished (in 2002 it was of 20.8 times) but against Bulgaria the difference was approximately maintained (in $2002,21 \%$ )

The annual dynamics of the minimum wage was in the period 2000-2008 of 19.8\%, superior to the one in Bulgaria of $8.2 \%$ and of New Member States of $7 \%$.

Table no. 4

Minimum Statutory wage, 2000-2008 (\%)

\begin{tabular}{|l|r|c|c|c|c|c|c|c|c|r|}
\hline & 2000 & 2001 & $\begin{array}{c}200 \\
2\end{array}$ & 2003 & 2004 & $\begin{array}{c}200 \\
5\end{array}$ & $\begin{array}{c}20 \\
06\end{array}$ & 2007 & 2008 & $\begin{array}{r}2000- \\
2008^{* *}\end{array}$ \\
\hline $\begin{array}{l}\text { Luxembou } \\
\text { rg }\end{array}$ & 1,9 & 0,1 & 3,9 & 0,0 & 1,4 & $-1,3$ & 1,5 & $-2,7$ & 0,4 & 0,6 \\
\hline Old EU ** & 0,4 & 1,8 & 0,7 & 0,1 & 3,2 & 1,7 & 1,7 & 1,6 & 0,2 & 1,3 \\
\hline Bulgaria & 8,5 & 18,3 & 4,2 & 6,8 & 18,9 & 0,7 & 5,1 & 14,6 & $-2,9$ & 8,2 \\
\hline Rumania & 77,2 & 5,1 & 56,1 & $-3,3$ & $-1,2$ & $-2,6$ & $\begin{array}{c}11, \\
6\end{array}$ & 23,3 & 12,1 & $\mathbf{1 9 , 8}$ \\
\hline Slovakia & $-2,0$ & 4,6 & 16,8 & 1,0 & $-0,6$ & 3,3 & 5,8 & 4,7 & 5,9 & 4,4 \\
\hline Slovenia & 1,1 & 8,5 & 2,0 & 1,9 & 1,7 & 1,8 & - & $-0,6$ & 3,9 & 2,2 \\
\hline $\begin{array}{l}\text { Czech } \\
\text { Republic }\end{array}$ & 30,6 & 8,5 & 7,4 & 7,4 & 4,7 & 3,6 & 5,5 & $-3,0$ & $-6,3$ & 6,5 \\
\hline Hungary & 46,9 & 15,9 & $-5,2$ & 1,3 & 0,7 & 6,1 & 0,8 & $-2,6$ & $-2,4$ & 6,8 \\
\hline $\begin{array}{l}\text { New EU } \\
* *\end{array}$ & 15,7 & 7,4 & 10,3 & 4,4 & 3,0 & 3,8 & 7,3 & 11,4 & $-0,6$ & 7,0 \\
\hline $\begin{array}{l}\text { Total of } \\
\text { EU 20** }\end{array}$ & 8,8 & 4,9 & 6,0 & 2,5 & 3,1 & 2,9 & 4,7 & 7,0 & $-0,3$ & 4,4 \\
\hline
\end{tabular}

* The amounts of minimum wages are compared on 1 January of each year. The real minimum wages calculations are based on the harmonised consumer price ** Unweighted average Source: WSI Minimum Wage Database 2009 
Although necessary, as safety net for limiting the incidence of poverty by its level, the minimum wage cannot represent an efficient instrument of social protection nor a stimulus for economic growth at least for the following considerations:

a) the level of the minimum wage in Romania is under the necessary threshold for ensuring the minimum subsistence ${ }^{10}$

\section{A necessary link between the minimum subsistence basket and the minimum wage?}

The trade unions within the negotiations regarding the minimum wage considered also the level of the minimum subsistence basket asking that the minimum wage "should at least cover the minimum subsistence basket" (BNS, 2005) ${ }^{11}$. BNS is of the opinion that having a job is the most efficient way of insurance against the poverty and social exclusion risk, yet not always enough, especially in the case of families of two or more persons depending on a single employed. If in 2005the National Trade Union Block requested the taking into account of the minimum subsistence basket in the bargaining, in $2007^{12}$ the unionists are more reluctant " the minimum subsistence basket is closer, in fact, to the average wage and the economy cannot bear yet another pressure", considered the experts In addition, the unionists appreciated that the minimum wage should be higher than the minimum subsistence basket in order to ensure a decent level of living for each employee" (Ovidiu Jurca, vice-president of the National Trade Union Block). "The minimum wage should cover the expenditures of the subsistence basket, and the minimum wage should be wage and not social assistance". (Ilie Sebanescu, economic analyst). In addition, it should be mentioned that food held a share of $37 \%$ in the subsistence basket due to the low level of incomes - the prices for the main categories of food are very close to the ones in the EU, and the incomes of Romanians represent a third from the average earnings of the Europeans. "The value of the minimum subsistence basket is of 650-700 lei, while the minimum wage determined for 2008 is of 500 lei. "There isn't any type of correlation" "13. The discrepancies between the levels of the minimum subsistence basket increased, so that for instance in May 2009 it was of about 720 de lei, yet this income ensures only the minimum subsistence wage. "The minimum wage on economy should increase up to 800 lei in view of drafting the Unified Wage

\footnotetext{
10 The computation methodology of the minimum subsistence basket was elaborated by an expert group of the ministries, trade unions and researchers from research institutes having an exclusively normative and not statistical character. During the year 2000, National Commission for Indexation debated on and approved the computation methodology of the minimum subsistence basket. By the Governmental Emergency Ordinance no. 217/2000, approved by Law no. 554/2001, were passed the structure, components and value of the minimum monthly subsistence basket computed for the prices of the month of October 2000. In accordance with Art. 2 from G.E.O. no. 217/2000, the value of the minimum subsistence basket was updated quarterly by the National Institute of Statistics and its values was approved by Governmental Resolution, the last being GR 1079/2003 about approving the value of the minimum monthly subsistence basket for the second quarter of the year 2003. In the year $\mathbf{2 0 0 6}$ is established, at the initiative of the Ministry of Labour and Social Solidarity, the Technical Commission regarding the establishment of the minimum wage as tripartite technical body, with the main purpose of determining the minimum wage. The substantiation of the minimum wage was not based on the minimum monthly subsistence basket. Within the commission was elaborated a Protocol signed by all three parties by which the value of the minimum wage is established for the years 2007 and 2008, as well as the growth limits of the minimum wage up to the year 2009.

${ }^{11} 16$ Sept 2005, Saptamana Financiara, http://www.sfin.ro/articol_2567

${ }^{12}$ In 2007, on the background of increased prices for food products, of higher prices for electric energy, natural gas and car fuels, more and more often is brought into discussion the topic of assessing the minimum subsistence basket. The opinions are divided with respect to the necessity of evaluating this basket, particularly related to its usefulness for determining a new level of the minimum wage on economy.

${ }^{13}$ Dragos Frumosu, Chairman of the Trade Unions' Federation from the Food Industry, http://www.gardianul.ro /2007/11/15/economie-c1/cosul_de_consum_modificat_de_guvern_pentru_a_justifica_salariile_mici_ale_rom_nilor-
} s104586.html 
Law.....increasing the minimum wage on economy to 800 lei is less probable in this year, if this measure is not completed by other measures for stimulating the business environment "14. In drafting the wages' law it was opted for the variant of a minimum on the wage grid for personnel paid from public funds of 705 lei which has no connection to the minimum wage of the private sector, not with the minimum subsistence or with the subsistence basket. Moreover, the employers' organisations alleged that the economy cannot bear a minimum wage higher than $650 \mathrm{lei} /$ month (the enforced minimum wage was of 600 lei/month), any higher level requiring accompanying measures of support of the government.

b) the estimated increase of the minimum wage for the period up to 2015 is under the actual needs of the economy and households;

Minimum wage increasing program
In accordance with the EU recommendations of the revised Social European Charts and the
ones for increasing social cohesion, the trade unions, after major protest action, signed a
tripartite agreement on the medium-term development of the minimum wage $2008-2014$.
They acknowledge that "the major problem in Romania is the gap at economic and social
level that separates us from developed European countries and which is synthetically
expressed in indicators such as GDP value/capita, the value of the gross average wage,
the share of the minimum gross average in gross average earnings"
In the framework of the Tripartite Agreement is established a gradual increase of the
minimum wage in the period $2008-2014,-37 \%$ in $2010,40 \%$ in $2011,44 \%$ in $2012,47 \%$ in
2013 and $50 \%$ in 2014 . For the year 2010 the trade unions required the wage increase to
minimum 705 lei - this meaning a linear increase of the wages fund with productivity and
inflation, as intended by the employers' organisations (B. Hossu, Cartel Alfa, 2009$)^{16}$. Due to
the crisis, the initial proposal of readjusting the level of the minimum wage at the half of the
year 2009 was reconsidered, currently bargaining being underway for a minimum wage for
the year 2010.

The economic crisis did not allow for complying with the provisions of the memorandum for increasing the minimum wage and therefore the purchasing power decreased due to inflation.

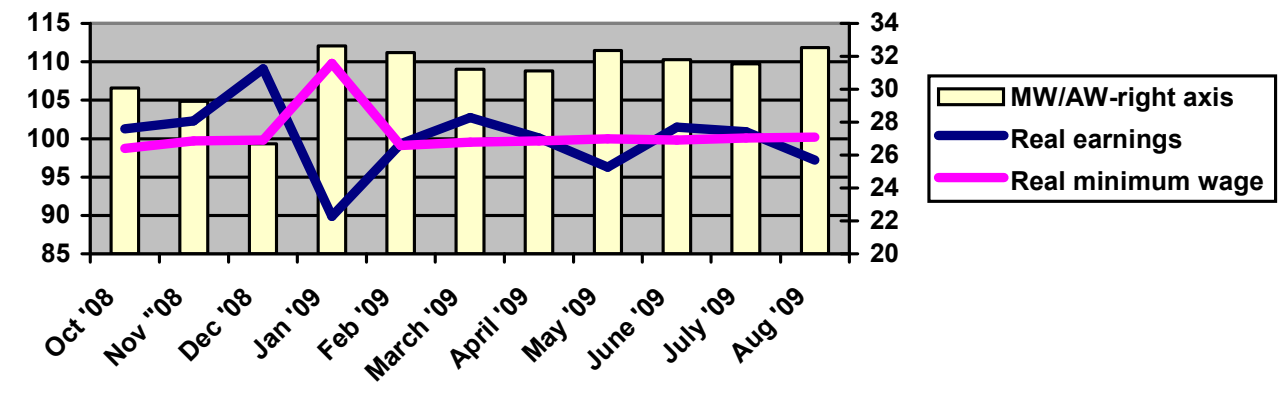

\footnotetext{
${ }^{14}$ Chairman of the National Trade Union Block (BNS), Dumitru Costin, http://business.rol.ro

${ }^{15}$ Tripartite agreement for ensuring the increase of the gross minimum wage in the period 2008 - 2014 http://x.gov.ro/ presa/documente/200807/2007\%20Acord\%20tripartit\%20pentru\%20cresterea\%20salariului\%20 minim\%20brut.pdf

${ }^{16}$ Statement of the Chairman "Cartel Alfa", Bogdan Hossu. Leader "Cartel Alfa". http://stiri.kappa.ro/social/sindicatelemajorarea-salariului-minim/stire_226868.html
} 


\title{
Fig. no.4 - Minimum wage Oct 2008- August 2009 (changes against previous month)
}

\author{
Source: Basedon NIS data
}

The trade unions claim that the suggested level for 2009 (for the public sector) is under the minimum of the consumption basket which in the middle of the year 2009 was estimated to 720 lei/month. The increases forecasted for prices and raised excises for some products will adjust the purchasing power of the minimum wage, with effects on poverty incidence (an increase of electric energy prices is foreseen of about $30 \%$, also for gas by $20 \%$, of tobacco excises and a decrease of excises for luxury products -yachts, jewellery, perfumes etc!)

The private environment even though not acknowledging the need of higher incomes of the population, appreciates that it cannot bear the effects of the increase suggested for the public sector in 2010, justifying the imposed restrictions by productivity/performance and suggesting an increase to maximum 650 lei/employee as of the second half of 2010. The employers' organisations agree to a minimum wage higher by $8.3 \%$ than the current one (650 lei) but associated with a package of fiscal diminishments to make up for the difference of up to 705 lei/month (as provided for the minimum wage in the wage grid for state employees).

\section{Conclusions. Some policy measures. The role of minimum wage}

The economic and financial crisis determines an unprecedented increase in unemployment and poverty. Wage employment decrease or/and incomes reduction have also been significant so far and could get worse in the coming months. The ILO estimates that, even if an economic recovery begins to take hold in 2009 or 2010, a global jobs crisis could linger on for six to eight years. In this context the role of minimum wage increased as active instrument for poverty risk reduction, employment for youth and factor to support domestic demand.

The Global Jobs Pact specifically calls on governments to consider options such as minimum wages, which can reduce poverty and inequality, increase demand and contribute to economic stability.

The minimum wage has always been a highly controversial issue for social partners in Romania and remains on top of trade unions' agenda. The level of the minimum wage is set by government decision, and prior consultation with trade unions is mandatory.

Even after a considerable growth dynamic in the last 20 years, the minimum wage on economy enforced in Romania remains one of the lowest within a Member State of the European Union. Only our neighbours from Bulgaria earn less. In our case the gross minimum wage on economy is almost 12 times lower than in Luxemburg, the country where this threshold is the highest in Europe, and half of the one in other countries of the region. The value is closer to the one used in Albania.

For Romania, the policy of the minimum wage requires reconsideration with respect to the link between the level of granted wage and labour productivity, respectively the value added generated by paid work at the level of the minimum wage. But, as level, it remains under the subsistence level hence its valences of social protection, as instrument for diminishing poverty incidence remain only at declarative level. The granted fiscal facilities are weakly performing (deductibility from wage taxes of the amount of 250 lei from the total of 600 lei minimum wage at present), and corresponding social contributions increase the wage costs to a level barely sustainable for economic agents who prefer alternatives such as dual payment of labour, or informal employment. Such behaviours generate short-term nominal benefits, but cannot support the improvement of behaviours on labour market.

The negotiation of wages from the wages grid takes into account, in practice, the level of the minimum wage level as well as the subsistence minimum. 
When talking about the future, the viewpoint of employers' organisations still agrees with the one of the unions: "It is very important to reach the level of the minimum wage from the other countries of the Euro area as to have compatibility. Up to 2015 it is necessary to have an ascending trend of wages. Nevertheless it should be in direct relationship to productivity.

Thus, we consider that a minimum wage policy should include at least the following:

- associating the increase of the minimum wage with productivity for what exceeds the inflation level;

- associative fiscal facilities that should stimulate the employer in promoting employment in the real economy, meaning the correlation of a fiscal burden that would allow that the value added corresponding to a paid job at the level of the minimum wage be higher than the total cost of related work;

- promoting wage packages that combine earnings with integral fiscality with complementary incomes corresponding to some remuneration instruments with total or partial fiscal deductibility - lunch tickets, gift vouchers, etc;

- stimulating employment of young graduates by fiscal facilities or partial financing of jobs on which they are employed, according to the qualification level obtained through schooling, as it is known that they can generate performance and quality on short-term.

It should be mentioned that these measures are associated on labour market with other instruments and elements of policy related to flexible, performance employment of supporting the promotion of lifelong learning which potentially generate productivity increase and induce wage increases, hence diminished poverty risk by advancement on the wage grid based on activity (active labour market policy).

\section{References:}

1. Parlevliet J and Xenogiani T (2008), Report on Informal Employment in Romania Working Paper No. 271, with the contributions of Catalin Ghinararu and Manuela Stanculescu OECD Development Centre, July 2008

2. Paternoster A (2004), Minimum Wages EU Member States, Candidate Countries and the US 2004, Population and Social Conditions, European Communities 10/2004.

3. Poot J ed, Waldorf B, Leo van Wissen (2009), International economic integration and migration: the case of Romania, Chapter 11, in Migration and Human Capital, , Edward Elgar Publishing House, 2008, published in 2009 p.225-247; UK, ISBN 978-1-84720-084-6; joint author;

4. Senatori I. (2008), Indicators of youth employment in a comparative perspective: The Question of „Decent work” and productive employment, IIRA 5th African Regional Congress Cape Town, 26 -28 March 2008, Graduate School of Business, Universiy of Cape Town.

5. Schmidt, V., Whitehead D.V., (2009), Wage institutions, practices and policies in the financial and economic crisis. Overview of the Western Balkans and selected EU Member States, "This paper has been prepared to stimulate discussion at The subregional high level conference on 'The Impact of the Financial and Economic Crisis: Wage Fixing and Policy Responses', held in Sarajevo, 5-6 November 2009.

6. Vasile, V (2009), Labour market - Romania's Report - paper presented at The subregional high level conference on 'The Impact of the Financial and Economic Crisis: Wage Fixing and Policy Responses', held in Sarajevo, 5-6 November 2009.

7. Zaman Gh., V.Vasile (2005), Migratia fortei de munca si dezvoltarea durabila a Romaniei. Abordari teoretico-metodologice. Sistem de indicatori si modele de analiza (Labour force migration and Romania's sustainable development), coordinator and joint author, 2005, Ed Expert, $237 \mathrm{p}$

8. National Bank of Romania (BNR), (2009), Buletin de Conjunctură, Anul XII, nr. 138, iunie 2009.

9. EC (1996) -The European Social Charter, 1996 
10. EC (2008) - Policy Paper on Youth Employment, Council of Members/ Extraordinary General Assembly 2-3 May 2008 (Castelldefels, Catalonia - Spain).

11. EC (2009) - A new era of EU youth policies, Brussels, 27 April 2009

12. EC (2009) - An EU Strategy for Youth - Investing and Empowering. A renewed open method of coordination to address youth challenges and opportunities, COMMISSION OF THE EUROPEAN COMMUNITIES, Brussels, 27.4.2009, COM(2009) 200 final

13. ILO (2008) - Global employment trends for youth, October 2008, International Labour Office Geneva

14. ILO (2009) - Global Employment Trends January 2009, International Labour Office Geneva: ILO, 2009, 54 p.

15. ILO (2009) -Tackling the global jobs crisis. Recovery through decent work policies. International Labour Conference, 98th Session 2009, Report I(A), ILO Geneva.

16. International Monetary Fund (IMF), (2009), Romania: Letter of Intent and Technical Memorandum of Understanding, Bucharest, April 24, 2009

17. International Monetary Fund (IMF), (2009), Romania: Request for Stand-By Arrangement-Staff Report; Staff Supplements; and Press Release on the Executive Board Discussion, June 2009, IMF Country Report No. 09/183

18. National Bank of Romania (NBR), (2009)- Report on financial stability 2009, NBR, June 2009

19. National Commission for Prognosis(NCP), (2009), Autumn Preliminary Forecast 2009

20. World Bank (WB), (2009), World Development Indicators, Poverty data, A supplement to World Development Indicators 2008 